J. Dairy Sci. 96:4773-4783

http://dx.doi.org/10.3168/jds.2013-6598

(C) American Dairy Science Association ${ }^{\circledR}, 2013$.

\title{
Invited review: The effect of native and nonnative enzymes on the flavor of dried dairy ingredients
}

\author{
R. E. Campbell and M. A. Drake ${ }^{1}$ \\ Department of Food, Bioprocessing and Nutrition Sciences, Southeast Dairy Foods Research Center, North Carolina State University, \\ Raleigh 27695
}

\begin{abstract}
Dried dairy ingredients are used in a wide array of foods from soups to bars to beverages. The popularity of dried dairy ingredients, including but not limited to sweet whey powder, whey proteins and milk powders, is increasing. Dried dairy ingredient flavor can carry through into the finished product and influence consumer liking; thus, it is imperative to produce a consistent product with bland flavor. Many different chemical compounds, both desirable and undesirable, contribute to the overall flavor of dried dairy ingredients, making the flavor very complex. Enzymatic reactions play a major role in flavor. Milk contains several native (indigenous) enzymes, such as lactoperoxidase, catalase, xanthine oxidase, proteinases, and lipases, which may affect flavor. In addition, other enzymes are often added to milk or milk products for various functions such as milk clotting (chymosin), bleaching of whey products (fungal peroxidases, catalase to deactivate hydrogen peroxide), flavor (lipases in certain cheeses), or produced during the cheesemaking process from starter culture or nonstarter bacteria. These enzymes and their possible contributions will be discussed in this review. Understanding the sources of flavor is crucial to produce bland, flavorless ingredients.
\end{abstract}

Key words: dairy ingredient, enzyme, flavor

\section{INTRODUCTION}

\section{Brief History of Enzymes}

The word "enzyme" was first introduced in 1878 by W. Kuhne, and in 1883 E. Duclaux introduced the term "substrate" (Fox and Kelly, 2006a). Although enzyme activity was identified previously, it was not until 1926 that B. Sumner crystallized the first enzyme (urease) from jack bean meal at Cornell University (Ithaca, NY), proving definitively that enzymes existed, for which he

Received January 19, 2013.

Accepted May 5, 2013.

${ }^{1}$ Corresponding author: maryanne_drake@ncsu.edu later received the Nobel prize (1946; Kosikowski, 1988). Since then, a variety of enzymes have been characterized in a wide array of foods, including milk. The history of indigenous enzymes in bovine milk has been reviewed extensively (Fox and Kelly, 2006a,b).

\section{Nomenclature of Enzymes}

Enzymes are divided among 6 major classes (Table 1). Each class is then divided into subclasses, each subclass divided into sub-subclasses, and each sub-subclass contains several enzymes. For example, catalase is EC 1.11.1.6. The first number (1) refers to the enzyme class of oxidoreductases, the second number (11) refers to the subclass of enzymes that act on a peroxide as an electron acceptor, the third number (1) refers to the subsubclass of peroxidases, and the last number (6) identifies this enzyme as a catalase within the sub-subclass [Nomenclature Committee of the International Union of Biochemistry and Molecular Biology (NC-IUBMB); http://www.chem.qmul.ac.uk/iubmb/enzyme/].

\section{Enzymes in Bovine Milk}

Indigenous, exogenous, and endogenous enzymes can be found in dairy ingredients. Indigenous enzymes are those that are found naturally in bovine milk. Indigenous enzymes come from 4 principal sources in fluid milk: somatic cells, secretory cell cytoplasm, the milk fat globule membrane (MFGM), or blood plasma through "leaky junctions" between mammary cells (Fox and Kelly, 2006a). Over 60 indigenous enzymes have been identified to date in bovine milk; however, milk does not contain the substrates for many of these enzymes (Fox, 2003). Nonetheless, native milk enzymes are of significant importance in the following ways: indices of mastitic infection, preservation of milk quality, indices of thermal history of milk, antimicrobial activity, as a commercial source of enzymes, or deterioration (Fox and Kelly, 2006a). In addition to indigenous enzymes, other enzymes that are not native to milk are often added to milk or milk products for various functions such as milk clotting (chymosin), bleaching of whey products (fungal peroxidases, catalase to deactivate hy- 
Table 1. Major classes of enzymes [Nomenclature Committee of the International Union of Biochemistry and Molecular Biology (NC-IUBMB); http://www.chem.qmul.ac.uk/iubmb/enzyme/]

\begin{tabular}{lll}
\hline $\begin{array}{l}\text { Enzyme class (EC) } \\
\text { number }\end{array}$ & Class name & Function \\
\hline 1 & Oxidoreductases & Catalyze oxidation or reduction reactions \\
2 & Transferases & Catalyze the transfer of specific chemical moieties \\
3 & Hydrolyases & Hydrolyze substrates with concomitant uptake of water molecules \\
4 & Lyases & Remove or add specific chemical moieties to their substrates \\
5 & Isomerases & Catalyze isomerization \\
6 & Ligases & Catalyze the synthesis or bonding together of substrate units \\
\hline
\end{tabular}

drogen peroxide), flavor (lipases in certain cheeses), or produced during the cheesemaking process from starter culture bacteria (Campbell et al., 2011a,b). Exogenous enzymes are those that are added to milk during processing (for example, chymosin), whereas endogenous enzymes are those that are present in the food, such as enzymes produced by microorganisms either by deliberate inoculation (cheese culture) or by unintentional growth (psychrotrophic bacteria; Table 2). Enzymes can have multiple functions; this review will focus on the flavor of milk and milk products, including dried dairy ingredients, due to native and nonnative enzymes.

\section{Flavor of Dried Dairy Ingredients}

Flavor is considered the single most important factor in determining the success or failure of a food product (Morr and Ha, 1991; Drake, 2007). In general, dairy products display a wholesome and flavorful image, making them well accepted by consumers. Dairy foods can possess 2 types of off-flavors: those that are already present in the milk and those that develop later as a consequence of actions, such as processing (Bodyfelt et al., 1988). Dried dairy ingredients are expected to have a delicate and bland flavor that is undetectable in finished goods (Drake, 2006). Undesirable flavors that carry through to the finished product limit the utilization of dairy ingredients.

Many different chemical compounds, both desirable and undesirable, contribute to the overall flavor of fluid and dried whey and dried whey ingredients, making the flavor very complex (Carunchia Whetstine et al., 2003, 2005; Drake et al., 2009). Lipid oxidation is responsible for many volatile compounds that contribute to off-flavors (Morr and Ha, 1991; Carunchia Whetstine et al., 2005; Carunchia Whetstine and Drake, 2007; Mortenson et al., 2008; Whitson et al., 2010; Liaw et al., 2011). The reaction of oxygen with unsaturated FA causes a wide variety of flavor-active volatile compounds including methyl esters, ketones, aldehydes, and FFA (Morr and Ha, 1991; Carunchia Whetstine et al., 2003, 2005; Liaw et al., 2011). The role of enzymes as a catalyst for lipid oxidation will be explored in this review.

\section{INDIGENOUS ENZYMES}

\section{Lactoperoxidase (EC 1.11.1.7)}

A member of the oxidoreductase family, lactoperoxidase (LP) plays an important role in protecting newborn infants against pathogenic microorganisms (Seifu et al., 2005). Lactoperoxidase is a normal component of mammalian milk, and has been found in all mammalian milks (Seifu et al., 2005). Unlike many other enzymes, LP is very heat stable, retaining its activity during the normal pasteurization of bovine milk, only being destroyed above $78^{\circ} \mathrm{C}$ (Seifu et al., 2005). The LP molecule contains a heme group in the center (Kussendrager and van Hooijdonk, 2000). Bovine LP consists of a single polypeptide chain containing 612 amino acid residues. Its molecular weight is approximately $78 \mathrm{kDa}$ and it has a high isoelectric point of 9.6.

Table 2. Indigenous, exogenous, and endogenous enzymes found in dried dairy ingredients and their potential to influence final ingredient flavor

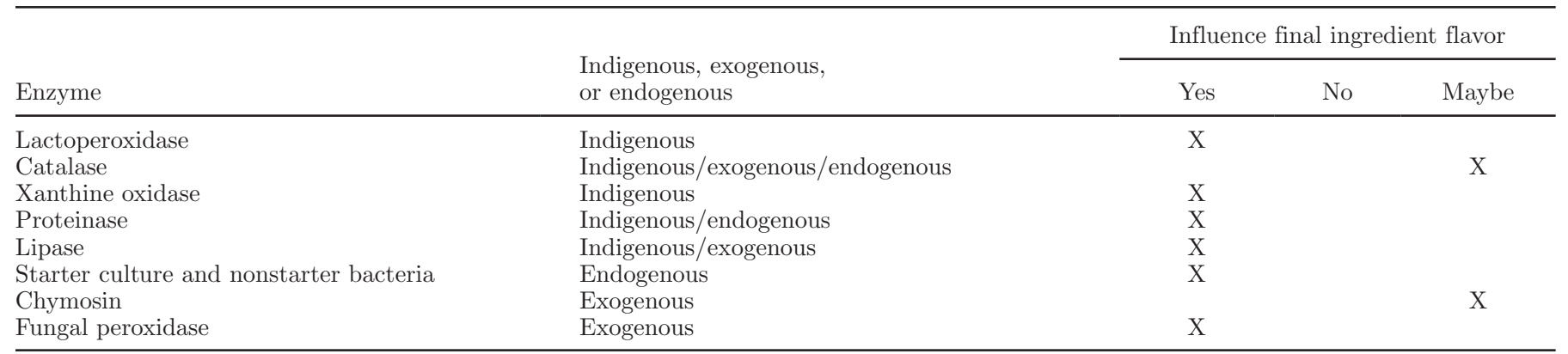


Lactoperoxidase is the second-most-abundant enzyme found in bovine milk, constituting about $0.5 \%$ of the serum proteins in raw milk (de Wit and van Hooijdonk, 1996). Variations in enzyme levels depend on the sexual cycle of the cow, season, feeding regimen, and breed (Kussendrager and van Hooijdonk, 2000). The LP system is most traditionally used as an antimicrobial system in developing countries without proper access to pasteurization equipment or cold storage (Seifu et al., 2005). It has recently been applied for bleaching of fluid Cheddar whey (Bottomley et al., 1989; Campbell et al., 2012; our unpublished data).

The LP system consists of 3 components: LP, hydrogen peroxide (HP), and thiocyanate $(\mathbf{S C N})$. All 3 of these components are necessary in sufficient amounts in order for the system to be active. The active LP system produces hypothiocyanate (OSCN), the major intermediate oxidation product of SCN, which inhibits bacterial growth and, in some cases, is bactericidal (Seifu et al., 2005). Other short-lived intermediates that may be formed, depending on reaction conditions, include cyanogen SCN, cyanosulfurous acid, and cyanosulfuric acid (Seifu et al., 2005). The oxidation of sulfhydryl groups in microbial enzymes and other proteins is considered key to the antimicrobial activity of the LP system (Seifu et al., 2005). In addition to OSCN, hydroxyl radicals and superoxide radicals are created, possibly causing other reactions in the matrix, such as bleaching or other Fenton-type side reactions causing increased lipid oxidation (Campbell et al., 2012; Jervis and Drake, 2013). Whether the LP system is used for antimicrobial purposes or for the bleaching of whey, the flavor of the milk or whey will be affected by the free radicals created and the oxidation of sulfhydryl groups. Lipid oxidation products have been documented in fluid whey and powdered whey protein concentrate (WPC) with $80 \%$ protein (WPC80) bleached by activating the LP system (Campbell et al., 2012). Lipid oxidation products are major contributors to off-flavors in dried dairy ingredients, often eliciting cardboard/stale flavors (Whitson et al., 2010, 2011). Undesirable flavor associated with sulfur compounds, such as the cabbage flavor produced by dimethyl trisulfide have been previously documented in dried dairy ingredients (Wright et al., 2006, 2009).

Although it is evident that the use of the LP system for the bleaching of fluid whey can produce off-flavors that carry through into the final dried whey protein powder (Campbell et al., 2012; our unpublished data), it is unlikely that flavors due to LP activity occur in dried milk ingredients such as milk protein concentrate or skim milk powder. Unlike fluid whey, to activate the LP system in fluid milk, SCN must be added as well as HP (Boulares et al., 2011). As such, the system can- not activate naturally even if the milk contains enough naturally present HP from aerobic bacteria to activate the LP system. The LP system in milk is used primarily in developing countries without proper processing equipment for pasteurization; thus, this milk would likely not be subjected to membrane filtration. Until recently (2009), the Codex Alimentarius prohibited the use of the LP system in milk and milk products traded internationally. In 2009, this restriction was lifted and "any trade in milk treated by the lactoperoxidase system should only be on the basis of mutual agreement between countries concerned."

Hydrogen Peroxide. Hydrogen peroxide is frequently added to activate the LP system, in either milk or whey, depending on the use of the LP system (antimicrobial or bleaching, respectively), if no HP is naturally present (Kussendrager and van Hooijdonk, 2000). Catalase-negative organisms (such as lactic acid bacteria) can generate enough HP under aerobic conditions to activate the LP system. Many lactobacilli, lactococci, and streptococci produce sufficient HP under aerobic conditions to activate the LP system (Seifu et al., 2005). If the LP system is not activated by native bacteria producing HP, exogenous HP must be added to activate the system (Reiter and Härnulv, 1982). Gram-negative, catalase-positive organisms (such as pseudomonas, coliforms, salmonellae, and shigellae) are not only inhibited by the LP system, but may be killed by the activated LP system (Seifu et al., 2005). Gram-positive, catalasenegative bacteria (such as streptococci and lactococci) are generally inhibited but not killed by the LP system (Seifu et al., 2005). If raw milk is stored at $\leq 15^{\circ} \mathrm{C}$, the LP system can effectively preserve raw milk for 24 to 26 h (Reiter and Härnulv, 1982). To activate the LP system in raw milk, small amounts $(8.5 \mathrm{mg} / \mathrm{kg})$ of HP are added exogenously (FAO/WHO, 2005). Exogenous $\mathrm{HP}$ added in small amounts $(20 \mathrm{mg} / \mathrm{kg})$ is effective at activating the LP system for the bleaching of pasteurized, fat-separated fluid whey (Campbell et al., 2012). It is unlikely that the concentration of HP used for activation of the LP system directly causes any flavors in dried dairy ingredients, but rather the undesirable flavors are indirectly related to HP concentration and subsequent LP activity.

Thiocyanate. Thiocyanate is widely distributed in animal tissues and secretions. In fresh bovine milk, 1 to $15 \mathrm{mg} / \mathrm{kg}$ has been reported (Seifu et al., 2005). The SCN concentration in milk varies with breed, species, udder health, and type of feed (Kussendrager and van Hooijdonk, 2000). Two major dietary sources of SCN exist in bovine milk: glucosinolates and cyanogenic glucosides. These can be found in cabbage, kale, Brussels sprouts, cauliflower, turnips, rutabaga, cassava, potatoes, maize, millet, sugar cane, peas, and beans (Seifu 
et al., 2005). There may or may not be enough SCN naturally present to activate the LP system in raw milk (Seifu et al., 2005). As such, the Codex Alimentarius recommends that SCN in the raw milk be increased to $15 \mathrm{mg} / \mathrm{kg}$ by adding powdered SCN and mixing thoroughly before the addition of HP to activate the system (FAO/WHO, 2005). In fluid whey, SCN appears to be naturally high enough to activate the LP system and bleach sufficiently (Bottomley et al., 1989, Campbell et al., 2012); however, extensive studies have not yet been conducted using various sources of milk.

\section{Catalase (EC 1.11.1.6)}

Catalase was among the first enzymes demonstrated in milk (1897); however, it was not formally reported until 1911 (Fox and Kelly, 2006a). Catalase decomposes $\mathrm{HP}$ as follows: $2 \mathrm{H}_{2} \mathrm{O}_{2} \rightarrow 2 \mathrm{H}_{2} \mathrm{O}+\mathrm{O}_{2}$. Catalases react with HP in many ways and none of these reactions are adequately understood. Catalase can be an indigenous, exogenous, or endogenous enzyme, as it is found indigenously in milk and can also be produced during cheese manufacture by coryneform bacteria and yeasts; however, it may also be added exogenously in some dairy processes (Fox and Kelly, 2006a; Kang et al., 2010). In raw milk, high levels of catalase are associated with mastitic infection and high levels of SCC in the milk (Fox and Kelly 2006a). Similar to many other enzymes, catalase activity varies in milk due to feed, stage of lactation, and mastitis (Fox and Kelly, 2006a). Catalases are usually associated with the MFGM, as the specific activity in cream is 12-fold higher than in skim milk (Kitchen et al., 1970).

Catalase is relatively heat labile, and is inactivated completely by heating at $65^{\circ} \mathrm{C}$ for $16 \mathrm{~s}$ (Fox and Kelly, 2006a). It is not a good indicator of cheese made from sub-pasteurized milk, as catalase is also produced during cheese ripening (Fox and Kelly, 2006a). Legally, catalase must be added to fluid whey or retentate that has been chemically bleached with HP to remove residual peroxide (US FDA, 2009). The ability of catalase to break down HP into water and oxygen helps to prevent the breakdown of HP into free radicals. Free radicals can go on to cause lipid oxidation, thus creating a many off-flavors commonly found in milk and dairy ingredients. In this sense, catalase may have a positive effect on flavor. However, catalase as a potential source of off-flavors in milk and dairy products has yet to be evaluated in detail.

\section{Xanthine Oxidase (EC 1.17.3.2)}

The terminology for the xanthine oxidase (XO) enzyme throughout the literature is confusing, at best.
The enzyme is often more correctly referred to as xanthine oxidoreductase (XOR; Harrison, 2006), but the term xanthine oxidase is used collectively for all forms of the enzyme, including not only XO but also xanthine dehydrogenase $(\mathrm{XDH})$. For the purposes of this paper, $\mathrm{XO}$ will solely be used for terminology of the enzyme. As its name implies, $\mathrm{XO}$ is an oxidoreductase and catalyzes oxidation and reduction reactions.

Xanthine oxidase has been found in the milk of all mammals tested, with particularly high activity in bovine milk (Silanikove and Shapiro, 2007). In milk, XO can be found in the MFGM (Harrison, 2006) and processing treatments that damage or alter the MFGM will subsequently affect the activity of XO in the milk (Fox, 2003). Xanthine oxidase activity is typically measured spectrophotometrically by the rate of uric acid formation monitored at $292 \mathrm{~nm}$ but can also be quantified via reverse-phase HPLC (Kelley et al., 2010). Xanthine oxidase is a nonspecific enzyme and has many different roles, but its most important role is its ability to produce HP, which can then serve as a substrate in the LP system (Fox, 2003; Fox and Kelly, 2006a). Hydrogen peroxide is produced in the presence of oxygen when the reduced flavin adenine dinucleotide cofactor reacts with oxygen divalently and forms HP (Kelley et al., 2010). Unlike other enzymes, treatments such as heating or homogenization cause the release of XO from the MFGM into the aqueous phase of the milk and render the enzyme more active (Dwivedi et al., 1973; Fox, 2003). Until recently, it was thought that $\mathrm{XO}$ was concentrated in the cream fraction; however, a recent study proved that the highest $\mathrm{XO}$ activity in bovine milk was located in the serum phase due to the small contribution of the MFGM to the total mass of the milk (Silanikove and Shapiro, 2007). This enzyme is capable of reducing oxygen to generate reactive oxygen species, superoxide, and HP (Harrison, 2006). As such, XO may play a role in antimicrobial activity in raw milk. It can also reduce nitrite, yielding reactive nitrogen species such as nitric oxide and peroxynitrite (Harrison, 2006). Because XO is a nonspecific enzyme, it has a broad range of activities, many applications in food (Dwivedi et al., 1973), and various flavor implications, which include the following:

An Index of Heat Treatment. The literature is conflicting on this issue. Natural variability in the level of XO activity in milk was once said to be too high for $\mathrm{XO}$ to be considered a good indicator of heat treatment (Griffiths, 1986). However, later studies suggested that $\mathrm{XO}$ could be a good indicator of milk heated in the 80 to $90^{\circ} \mathrm{C}$ range (Andrews et al., 1987).

Reduction of Nitrate in Cheese. Sodium nitrate is sometimes added to certain cheese varieties to prevent the growth of Clostridium tyrobutyricum to 
prevent flavor defects and late gas blowing in Dutch, Swiss, or other cheese varieties (Fox, 2003). Xanthine oxidase plays a key role in the bactericidal effect of added nitrate, as it is necessary to reduce nitrate to nitrite. Xanthine oxidase will then go on to reduce nitrite to nitric oxide. In the presence of oxygen, nitric oxide is reduced to superoxide. Superoxide reacts rapidly with nitric oxide to yield peroxynitrite. Both nitric oxide and peroxynitrite exhibit bactericidal properties in bovine milk (Harrison, 2006).

Lipid Oxidation. Due to the nonspecificity of the enzyme, XO has long been suspected in the oxidative deterioration of milk flavor (Dwivedi et al., 1973). Xanthine oxidase can excite stable triplet oxygen to singlet oxygen, which is a very strong prooxidant (Fox, 2003). It is also possible for XO to produce HP, which can then in turn react with other compounds to form free radicals and thus increase lipid oxidation (Kelley et al., 2010). Griffiths (1986) found that XO persisted even after heating at $80^{\circ} \mathrm{C}$ for $120 \mathrm{~s}$. Lipid oxidation products have been found in a variety of dried dairy ingredients, from WPC to milk powders, and are sources of cardboard flavor (Carunchia-Whetstine and Drake, 2007; Croissant et al., 2009; Campbell et al., 2011a; Whitson et al., 2011; Jervis et al., 2012). These flavors increase over time and can carry over into the finished product, influencing consumer acceptability.

Production of $\mathrm{H}_{2} \mathrm{O}_{2}$. Hydrogen peroxide is produced by XO, which serves as a substrate for LP, thus potentially activating the LP system. As discussed previously, the LP system exhibits bacteriostatic and bactericidal activity in fluid dairy products and is often used in less-developed countries where pasteurization and proper refrigeration are not an option. The LP system in fluid whey can be activated by small amounts of HP and when the LP system is activated in fluid Cheddar whey, it has great bleaching potential by generation of the oxidative compound OSCN (Bottomley et al., 1989; Campbell et al., 2012). Although enough HP may be produced by XO to activate the LP system, in milk, exogenous SCN must also be added, so it is unlikely HP produced from $\mathrm{XO}$ would unintentionally activate the LP system in milk; thus, off-flavors produced due to the LP system would probably not be present in dried milk products. However, in whey, enough SCN is naturally present, so it is probable that the HP produced from $\mathrm{XO}$ could unintentionally activate the LP system in whey. Whey protein concentrate bleached by the LP system was higher in aldehydes and sulfur compounds compared with traditional bleaching by the dairy industry (Campbell et al., 2012). Xanthine oxidase is an indirect source of off-flavors and any activation of the LP system in whey directly or indirectly may contribute to lipid oxidation off-flavors in dried whey ingredients.

\section{Proteinase (EC 3.4.-.-)}

Proteinases in milk can either be inherent in the milk (indigenous) or created by psychrotrophic bacteria during storage (endogenous). As proteinases span 2 different categories, they will be discussed within their respective sections. Heat treatments severe enough to eliminate proteolytic activity would be detrimental to milk protein functionality; thus, with the current heat treatments in the dairy industry, proteinases, both indigenous and exogenous, remain active in the final product (Chen et al., 2003). Proteinases can survive all heat treatments applied during the manufacture of milk powder (pasteurization and spray drying, and so on; Chen et al., 2003). Proteolysis is especially important in aged products such as cheese or in stored products such as dried dairy ingredients. Proteinases break down proteins, creating peptides and amino acids. Bitterness in stored milk powders has been attributed to proteolysis (Carunchia Whetstine and Drake, 2007).

Bovine milk is known to contain several indigenous proteinases; however, only 2 have been studied in detail: the principal milk proteinase plasmin (EC 3.4.21.7) and cathepsin D (EC 3.4.23.5; Fox and Kelly, 2006a). Many other proteinases exist in milk but are inactive due to the high redox potential of milk and thus are rarely studied (Fox and Kelly, 2006a). The physiological function of plasmin is to dissolve blood clots. Plasmin concentration and activity in bovine milk can vary due to seasonality, stress, diet, lactation, and mastitis and have been well reviewed previously (Bastian and Brown, 1996; Kelly and McSweeney, 2003). The plasmin system in bovine milk is rather complex and consists of several key components, including plasminogen activators and inhibitors (Figure 1). In milk, plasmin hydrolyzes peptide bonds (particularly $\beta$-CN; Fox, 2003). Various processing parameters and storage conditions influence plasmin activity. Thermal treatment associated with the pasteurization of milk can inactivate plasminogen inhibitors and thus increase plasmin activity (Kelly et al., 2006). Although optimum plasmin activity occurs at $37^{\circ} \mathrm{C}$, plasmin can still be active during cold storage of raw or pasteurized milk (Ismail and Nielsen, 2010). Plasmin activity has been linked to increased casein hydrolysis (Farkye and Fox, 1992). With the degradation of $\beta$-CN, the concentration of $\gamma$-CN increased concurrently (Farkye and Fox, 1992). Hydrolysis of proteins in milk can lead to a bitter taste. Milk that has been processed by UHT is often stored at room temperature $\left(22-25^{\circ} \mathrm{C}\right)$, which is closer to the plasmin optimum and temperature; thus, more casein hydrolysis may occur. This can ultimately lead to the gelation of UHT milk and poorer protein quality of nonfat dry milk (Ismail and Nielsen, 2010). Although plasmin is a very heat- 
stable enzyme and survives even UHT processing as discussed previously, it is not known whether plasmin survives milk protein processing steps which may include membrane filtration, evaporation, and spray drying, although it is very likely that it does (Chen et al., 2003). In cheese, plasmin contributes to the formation and degradation of water-soluble peptides in cheese, purportedly increasing the sensory quality of cheese (Bastian et al., 1991; Farkye and Fox, 1992). In addition, plasmin contributes to desirable texture changes that occur during cheese ripening (Ismail and Nielsen, 2010). Plasmin is active in whey protein products and acidic whey products have higher plasmin activity than sweet whey products (Hayes and Nielsen, 2000). Plasmin was still present and active in reconstituted commercial whey protein concentrates (both acidic and sweet), but its concentration varied considerably (Hayes and Nielsen, 2000). Recent studies of plasmin in whey have focused on the effect of high-pressure treatment, $\mathrm{pH}$, temperature, or processing (such as filtration) on activity (Crudden and Kelly, 2003; Crudden et al., 2005; Moatsou et al., 2008; Aaltonen and Ollikainen, 2011). It is possible that plasmin activity may have a negative effect on whey proteins and lead to undesirable flavors; however, this has yet to be studied.

Cathepsin D has not been studied nearly as extensively as plasmin and its full significance in fluid milk and milk products is still unknown. The primary biological function of this enzyme is protein degradation in lysosomes. Should this function fail, lipofuscin will accumulate in a variety of tissues and cause neurodegeneration and vision loss (Benes et al., 2008). Cathepsin $\mathrm{D}$ is relatively heat sensitive and is inactivated at $70^{\circ} \mathrm{C}$ (Fox, 2003). Similar to plasmin, cathepsin D is part of a complex system including inactive precursors to the enzyme (Fox and Kelly, 2006a). A high degree of correlation exists between SCC and cathepsin D activity in milk, although it is unknown if this is merely due to increased activation or increased production of the enzyme (Hurley et al., 2000). Cathepsin D cleaves $\alpha_{\mathrm{s} 1}-\mathrm{CN}$, $\beta-\mathrm{CN}$, and $\kappa-\mathrm{CN}$, although its milk-clotting properties are poor (Fox and Kelly 2006a). The peptides created from the cleavage of caseins could possibly create bitter taste in dairy products; however, the role cathepsin D plays on flavor has yet to be directly evaluated. Cathep$\sin \mathrm{D}$ is relatively heat labile (inactivated at $70^{\circ} \mathrm{C}$ for 10 min); however, recent studies suggest that it partially survives HTST pasteurization of milk (Hurley et al., 2000). Thus, in fluid milk, it is possible that cathepsin D plays a direct role in bitter taste, although this has yet to be studied. Due to other processing parameters involved in the manufacture of dried dairy ingredients, it is unlikely that cathepsin D would still be active in powdered product and play a direct role in flavor as the ingredient ages.

\section{Lipases (EC 3.1.1.-)}

Lipids that are present in dairy products can be enzymatically degraded by lipases either via either oxidation or hydrolysis. Lipases can generally be categorized as enzymes that catalyze the hydrolysis of lipids, which are the major lipid component of milk (Deeth, 2006). Lipoprotein lipase (LPL; EC 3.1.1.34) accounts for most of the native lipolytic activity in bovine milk and is normally associated with the casein micelle. Lipases may also come from bacterial sources such as Pseudomonas during the cold storage of milk. Lipases from these bacteria are notably different from LPL (Table 3). Lipolysis in milk can alter both flavor and functionality of dairy products (Deeth, 2006). In milk, there is enough natural LPL to cause raw milk to be unacceptably rancid in less than $10 \mathrm{~min}$ if the MFGM is ruptured and milk fat is exposed to the serum phase of the milk (Deeth, 2006). Realistically, rancidity does not occur at such a rapid pace, as LPL is associated with casein micelles and triglycerides are protected by the MFGM. Lipolysis occurs when LPL comes in direct contact with the substrate (triglycerides) and only occurs when the MFGM is physically damaged by various processes, including but not limited to agitation, homogenization, or temperature fluctuations (Fox, 2003). Raw milk is not exposed to excessive agitation for this reason. Lipoprotein lipase is relatively unstable and the

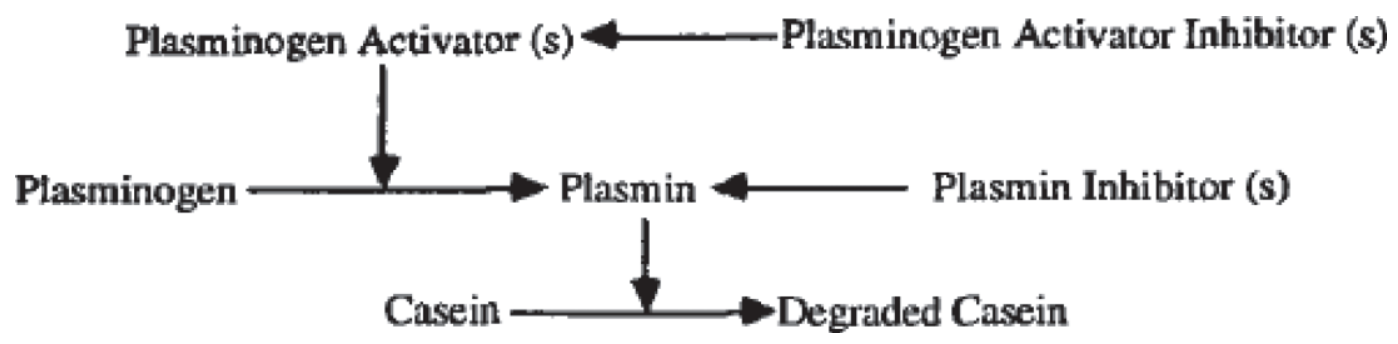

Figure 1. Plasmin system in fluid milk (Bastian and Brown, 1996). Used by permission. 
Table 3. Comparison of native and nonnative lipases in fluid milk (adapted from Deeth, 2006)

\begin{tabular}{ll}
\hline Milk lipoprotein lipase (LPL) & Lipases from bacteria \\
\hline $\begin{array}{l}\text { Heat sensitive; destroyed by HTST pasteurization } \\
\text { Milk fat globule membrane (MFGM) acts as a physical barrier }\end{array}$ & $\begin{array}{l}\text { Not very heat sensitive; stable to HTST and even UHT treatment } \\
\text { MFGM present no barrier }\end{array}$ \\
$\begin{array}{l}\text { Associated with fresh milk and cream } \\
\text { High levels present in raw milk }\end{array}$ & $\begin{array}{l}\text { Associated with stored products: UHT milk, cheese, butter, } \\
\text { milk powders } \\
\text { Trace levels present in raw milk }\end{array}$ \\
\hline
\end{tabular}

majority of the enzyme present in milk is inactivated by HTST pasteurization.

Lipolysis can be classified as either spontaneous or induced (Deeth, 2006). Specific chemical differences and sources are described below and these result in distinct sensory off-flavors: FFA flavors and oxidized flavors. Free fatty acid flavors are due to lipase activity and are caused by short-chain FFA, with flavors described as vinegar, cheesy, sweaty, and soapy (Drake et al., 2001; Singh et al., 2003). These FFA are generated by enzymatic hydrolysis of ester bonds of triglycerides. Oxidized flavors are due to autoxidation of FA and are characterized by cardboard, metallic, and mushroom flavors (Karagül-Yüceer et al., 2003).

Spontaneous Lipolysis. Some cows produce milk with spontaneous oxidized flavor, often described as fishy or metallic, which develops without the addition of exogenous oxidants or exposure to light (Timmons et al., 2001). Spontaneous oxidation of fluid milk is due to autoxidation of PUFA. Timmons et al. (2001) found that milk with high concentrations of PUFA and copper was the most susceptible to degradation. Although the causes are largely unknown, spontaneous or autoxidation of milk may be due to several factors: amount of lipase activity, the integrity of the MFGM, PUFA, and the balance of lipolysis-activating/inhibiting factors (Deeth, 2006). These factors can be due to feed quality, late lactation, and mastitis (Timmons et al., 2001; Deeth, 2006). Havemose et al. (2006) demonstrated that the composition of lipids in milk, especially the concentration of linolenic acid, was very important for autoxidation susceptibility and was directly influenced by the type of feed.

Spontaneously oxidized milk can develop rapidly (in the raw milk bulk tank) or more often, develop after pasteurization and several days of storage, with flavors intensifying over storage (Timmons et al., 2001). Spontaneous lipolysis occurs primarily on the farm and can be minimized by culling cows with high SCC, avoidance of freezing on the walls of the bulk tank, avoidance of cooling/warming cycles in the bulk tank, avoidance of excessive agitation (by pumps or agitators) in the bulk tank, and proper installation, maintenance, and operation of milking machines (Fox, 2003).
Spontaneous autoxidation in milk is very complex and is affected by pro- and antioxidants. The influence of antioxidants on the oxidative stability of milk has been studied (Lindmark-Månsson and Åkesson, 2000), but the role of antioxidants was determined to not be as important a factor in the determination of spontaneous lipolysis as FA profile (van Aardt et al., 2005; Havemose et al., 2006). Because spontaneous oxidation is still poorly understood and the resulting flavors are highly undesirable and negatively influence consumer acceptability of milk, it is very important to be able to rapidly evaluate raw milk for spontaneous oxidation susceptibility. Recently, J. K. Amamcharla and L. E. Metzger (South Dakota State University, Brookings, personal communication) developed a modified ferricreducing antioxidant power assay that measures the total antioxidant capacity of raw milk. Their assay was used successfully in both laboratory and commercial facility experiments to identify milk that was susceptible to oxidation.

Induced Lipolysis. Induced lipolysis occurs when the MFGM is disrupted by physical forces, exposing the lipid substrate to the lipase. The harsher the treatment or the longer time the treatment is applied, the greater the exposed surface area of the lipid and, consequently, the greater the rancidity. Damage during milk processing (agitation, homogenization, and temperature changes) can result in lipolysis; however, "most, if not all" LPL is deactivated during pasteurization, so rancidity is usually only seen in butter, cheese, or milk powders after a period of storage (Farkye and Fox, 1992; Deeth, 2006; Hickey et al., 2007). Lipolysis, the hydrolysis of lipids, leads to the formation of FFA. Short-chain FFA are of particular importance in the flavor of not only cheese, but other dairy products as well. Acetic acid (vinegar), butanoic acid (cheesy), pentanoic acid (sweaty), hexanoic acid (sweaty), heptanoic acid (sweaty), octanoic acid (sweaty/waxy), and nonanoic acid (sweaty) have previously been identified in both skim milk powder and whole milk powder as odor-active compounds (Carunchia-Whetstine and Drake, 2007). During storage of these powders, FFA and consequently undesirable flavors increased (Carunchia-Whetstine and Drake, 2007), suggesting that 
lipolysis is due primarily to postprocess contamination due to bacterial lipase (Collins et al., 2003). To create a product with acceptable flavor over time, not only must high-quality milk be used, but also extra care must be taken during processing to minimize bacterial lipases. For example, extra care should be taken to avoid product exposure to light. Should the product be exposed to light for extended periods of time either during storage or processing, odor-active compounds associated with light-induced oxidation may be present, including but not limited to pentanal, dimethyl disulfide, hexanal, heptanal, and nonanal (van Aardt et al., 2005).

\section{ENDOGENOUS ENZYMES}

\section{Bacterial Proteinases}

Two main types of spoilage bacteria can be found in milk and milk products: Pseudomonas and Bacillus species. Pseudomonas species are psychrotrophs and found commonly in raw milk due to contamination from the interior of the udder, cow teats, or milking and storage equipment (Chen et al., 2003). In pasteurized milk, psychrotrophs are the main cause of spoilage (Chen et al., 2003). Hayes et al. (2002) evaluated sensory aroma characteristics of milk spoilage by Pseudomonas species and generated 6 terms to describe spoiled milk: rotten hamburger, barn/fecal, shrimpy, medicinal, fruity, and baby vomit/cheesy. Proteinases from psychrotrophs, similar to many other enzymes, preferentially attack casein over whey proteins (Chen et al., 2003). Pseudomonas species have long been known to cause flavor defects in dairy products, with the earliest study on this subject being published in 1902 (Morgan, 1976). In particular, Pseudomonas fragi is responsible for the development of fruity flavors in processed dairy products. Lipases from this organism are able to hydrolyze milk fat and esterify butyric and caproic acids with ethanol (Morgan, 1976). Fruity flavor has been documented in skim and whole milk powders (Carunchia Whetstine and Drake, 2007). Although fruity flavor in fluid milk and dried dairy ingredients in not desirable, this flavor at low intensities may be desirable in Cheddar cheese (Carunchia Whetstine and Drake, 2007). In Cheddar cheese, the production of ethanol by the lactic starter culture, coupled with the presence of the esterase enzyme (similar to that found in Pseudomonas) commonly in some lactic acid bacteria, is responsible for fruity volatiles in Cheddar cheese (Morgan, 1976). Esterases are different from lipases in that esterases prefer soluble rather than emulsified ester substrates (Fox and Kelly, 2006a); thus, esterases are more likely to be found in whey, whereas lipases are more likely to be found in fluid milk.
With the improved control of postpasteurization contamination of non-heat-resistant psychrotrophs, the research focus in fluid milk has shifted to psychrotrophic spore formers and their potential effect on milk quality (Meer et al., 1991; Scheldeman et al., 2006). Bacillus species are environmentally ubiquitous and can be present in the raw milk or introduced during production, handling, and processing (Huck et al., 2008). In addition, Bacillus species have the capability to sporulate during adverse conditions, such as during HTST processing or during milk protein processing steps such as membrane filtration, evaporation, or spray drying. In a study conducted by Ranieri and Boor (2009), samples from pasteurized fluid milk across 18 dairy plants in 5 geographical regions of the United States revealed that more than $84 \%$ of gram-positive sporeforming isolates at 1, 7, and $10 \mathrm{~d}$ of refrigerated storage were of the Bacillus genus. Spores are very resistant to heat and chemical cleaning agents and may become a persistent problem on factory equipment, leading to further contamination during the powder making process (Chen et al., 2003). International concerns over spore counts in dried dairy ingredients are high (Yuan et al., 2012). Thermophilic spores are often used often used as hygiene indicators in processed products. Spores are considered spoilage organisms and if they germinate can display proteolytic and lipolytic activity and cause undesirable flavors (Burgess et al., 2010; Reginensi et al., 2011). Bacillus species are capable of producing multiple types of proteinases, thereby having more diverse proteolytic activity than proteinases from Pseudomonas species (Chen et al., 2003). Enzymatic activity results in the development of objectionable flavors and quality defects in dairy products (Meer et al., 1991). In addition, spores are capable of forming a biofilm on dairy equipment, leading to fouling and loss of production time (Burgess et al., 2010). Proteinases from both Bacillus species and Pseudomonas species have been documented to be heat stable, not only surviving processing but also remaining active in milk powders over long periods of storage (Chen et al., 2003). The direct effects of bacterial proteinases, particularly those due to Bacillus and the role of spore counts on sensory quality of dried milk ingredients has not been determined. Because dried dairy products are generally stored below $37^{\circ} \mathrm{C}$, it is unlikely that spoilage due to spore germination and vegetative growth would be problematic in dried ingredients (Burgess et al., 2010).

\section{Starter Culture}

Cheese flavor cannot be produced without starter bacteria and starter culture has been attributed to off-flavors in dried dairy ingredients, including WPC80 
and whey powder (Carunchia Whetstine et al., 2003; Tomaino et al., 2004; Liaw et al., 2010, 2011; Campbell et al., 2011a). Cheeses made from different starters have different flavors and, thus, wheys from different cheeses have different flavors (Carunchia Whetstine et al., 2003; Gallardo-Escamilla et al., 2005; Drake et al., 2009; Campbell et al. 2011b). Flavor of fluid whey from thermophilic starter differed from the flavor of fluid whey from mesophilic starter cultures (Campbell et al., 2011b; Liaw et al., 2011) and the flavor of whey from acid-set curd differed even further (Gallardo-Escamilla et al., 2005).

In the United States, the 2 main sources of liquid whey are Mozzarella and Cheddar. Liaw et al. (2011) reported that Mozzarella and Cheddar liquid whey were distinct in flavor and volatile compounds initially but that Cheddar whey was also more prone to lipid oxidation than Mozzarella whey. Whitson et al. (2011) reported similar findings with liquid Mozzarella and Cheddar whey retentates. Mesophilic Lactococcus lactis starter cultures, used to produce Cheddar cheese, influence flavor and oxidative stability of liquid whey (Carunchia Whetstine and others 2003; Tomaino and others 2004). Campbell et al. (2011a) recently demonstrated that lipid oxidation products were higher in concentration in dried WPC manufactured from mesophilic starter culture (Cheddar) whey compared with WPC from rennet-set whey. Lactic acid bacteria can produce HP, which can then in turn activate the LP system as previously discussed. The LP system produces free radicals, which then in turn create lipid oxidation products. Cheddar whey contains more lipid oxidation products than Mozzarella whey, suggesting that mesophilic starter cultures produce more HP and are more likely to activate the LP system than thermophilic starter cultures. In addition, the activity of the LP system is highly influenced by the heating temperatures that the curd and whey are subjected to and the $\mathrm{pH}$ at which the whey is drained; thus, more research needs to be conducted to pinpoint the cause of higher oxidation in Cheddar whey compared with Mozzarella whey.

Lactic acid bacteria convert lactose to lactic acid, along with the production of diacetyl and acetaldehyde, which contribute to flavor differences (Urbach, 1995; Smit et al., 2005). Whereas starter lactic acid bacteria are well known to cause flavor defects in dried dairy ingredients, nonstarter lactic acid bacteria (NSLAB) can also contribute to flavor. Naturally, NSLAB are very diverse between strains and as not all enzymes are present in a single strain, multiple strains are often used to create one cheese with desirable flavor (Smit et al., 2005). Nonstarter lactic acid bacteria can grow to large numbers (approximately $10^{8} \mathrm{cfu} / \mathrm{g}$ ) in cheese after storage and thus have become a widely studied topic (Cogan et al., 2007). As NSLAB are known to affect cheese flavor, they also potentially contribute to the flavor in dried dairy ingredients, although this topic has yet to be directly studied.

\section{EXOGENOUS ENZYMES}

\section{Rennet (Chymosin)}

Rennet is used to coagulate milk for the production of cheese. Most of the rennet added to the milk is lost in the whey (Bansal et al., 2007). Although residual rennet is minimal in cheese (5 to $15 \%$ of the original enzyme activity), it can have major flavor implications, primarily contributing to proteolysis during cheese ripening (Singh et al., 2003; Bansal et al., 2007). Bitter taste, from the production of bitter peptides, has also been attributed to residual chymosin in the cheese (Singh et al., 2005). Although chymosin carries over into fluid whey, it does not survive in dried whey protein, as fluid whey typically undergoes a pasteurization step either before or directly after fat separation. Pasteurization of the fluid whey inactivates the residual milk-clotting enzymes (Thunell et al., 1979). Should pasteurization be inadequate or not performed in a timely fashion, the chymosin may cause flavor defects due to proteolysis.

\section{Fungal Peroxidase}

In the United States, much of the whey comes from Cheddar cheese colored with annatto, a natural yellow-orange carotenoid, to impart desired cheese color (Kang et al., 2010). Although most of the annatto stays in the Cheddar cheese, some of the color goes into the whey (Kang et al., 2010). To produce the desired dried whey ingredients free of color, the whey must be bleached. Chemical bleaches, such as benzoyl peroxide or HP, are most commonly used. However, recently, enzymatic bleaching, either with the native LP or with exogenously added fungal peroxidase has gained momentum. Currently, there is one commercially marketed fungal peroxidase, MaxiBright (DSM, Heerlen, the Netherlands), for use in dairy products. MaxiBright works on a similar mechanism as LP in that it needs small amounts of HP to activate the system. Once activated, MaxiBright will bleach fluid whey faster than LP alone at cold temperatures (our unpublished data). The addition of fungal peroxidase may also provide extra insurance against the variable levels of LP in milk (Campbell et al., submitted). Similar to other chemical and enzymatic bleaching steps, other nonspecific oxidative reactions may occur and influence the flavor of the subsequent dried ingredients. 


\section{CONCLUSIONS}

Flavor directly influences liking of a product and thus purchase intent. The flavor of dried dairy ingredients can carry through into the finished product and influence consumer perception. Dried dairy ingredients are susceptible to many off-flavors from various processing parameters. Enzymes, both those naturally present and those added, can have a great effect on flavor and thus steps must be taken to ensure minimize undesirable flavors caused by enzymatic reactions. Understanding enzymes, their reactions, and subsequent off-flavors are key to designing a process that minimizes the negative effects of enzymes. Future work is needed to close the knowledge gap in previously discussed areas so that manufacturers can produce bland, desirable, consistent dried dairy ingredients for use in food processing.

\section{ACKNOWLEDGMENTS}

Funding was provided in part by the Dairy Research Institute (Rosemont, IL).

\section{REFERENCES}

Aaltonen, T., and O. Ollikainen. 2011. Effect of microfiltration of milk and plasmin activity. Int. Dairy J. 21:193-197.

Andrews, A. T., M. Anderson, and P. W. Goodenough. 1987. A study of heat stabilities of a number of indigenous milk enzymes. J. Dairy Res. 54:237-246.

Bansal, N., P. F. Fox, and P. L. H. McSweeney. 2007. Factors affecting the retention of rennet in cheese curd. J. Agric. Food Chem. 55:9219-9225

Bastian, E. D., and R. J. Brown. 1996. Plasmin in milk and dairy products: An update. Int. Dairy J. 6:435-457.

Bastian, E. D., K. G. Hansen, and R. J. Brown. 1991. Activation of plasmin with urokinase in ultrafiltered milk for cheese manufacture. J. Dairy Sci. 74:3669-3676.

Benes, P., V. Vetvicka, and M. Fusek. 2008. Cathepsin D-Many functions of one aspartic protease. Crit. Rev. Oncol. Hematol. $68: 12-28$.

Bodyfelt, F. W., J. Tobias, and G. M. Trout. 1988. The Sensory Evaluation of Dairy Products. Van Nostrand Reinhold, New York, NY.

Bottomley, R. C., R. D. Colvin, and M. Van Blanton, inventors. 1989 Decolorising of whey and whey products derived from whey. Express Foods Group Limited (Middlesex, GB2), assignee. US Pat. No. 4,888,184.

Boulares, M., M. Mankai, and M. Hassouna. 2011. Effect of thiocyanate and hydrogen peroxide on the keeping quality of ovine, bovine and caprine raw milk. Int. J. Dairy Technol. 64:52-56.

Burgess, S. A., D. Lindsay, and S. H. Flint. 2010. Thermophilic bacilli and their importance in dairy processing. Int. J. Food Microbiol. $144: 215-225$.

Campbell, R. E., E. J. Kang, E. Bastian, and M. A. Drake. 2012. The use of lactoperoxidase for the bleaching of fluid whey. J. Dairy Sci. 95:2882-2890

Campbell, R. E., R. E. Miracle, and M. A. Drake. 2011a. The impact of starter culture and annatto on the flavor and functionality of whey protein concentrate. J. Dairy Sci. 94:1185-1193.

Campbell, R. E., R. E. Miracle, P. D. Gerard, and M. A. Drake. 2011b. The effect of starter culture and storage on the flavor of liquid whey. J. Food Sci. 76:S354-S361.
Carunchia Whetstine, M. E., A. E. Croissant, and M. A. Drake. 2005 Characterization of dried whey protein concentrate and isolate flavor. J. Dairy Sci. 88:3826-3839.

Carunchia Whetstine, M. E., and M. A. Drake. 2007. The flavor and flavor stability of skim and whole milk powders. Pages 217-251 in Flavor of Dairy Products. K. R. Cadwallader, M. A. Drake, and R. McGorrin, ed. ACS Publishing, Washington, DC.

Carunchia Whetstine, M. E., J. D. Parker, M. A. Drake, and D. K Larick. 2003. Determining flavor and flavor variability in commercially produced liquid Cheddar whey. J. Dairy Sci. 86:439-448.

Chen, L., R. M. Daniel, and T. Coolbear. 2003. Detection and impact of protease and lipase activities in milk and milk powders. Int. Dairy J. 13:255-275.

Cogan, T. M., T. P. Beresford, J. Steele, J. Broadbent, N. P. Shah, and Z. Ustunol. 2007. Invited review: Advances in starter cultures and cultured foods. J. Dairy Sci. 90:4005-4021.

Collins, Y. F., P. L. H. McSweeney, and M. G. Wilkinson. 2003. Lipolysis and free fatty acid catabolism in cheese: A review of current knowledge. Int. Dairy J. 13:841-866.

Croissant, A. E., E. J. Kang, R. E. Campbell, E. Bastian, and M. A. Drake. 2009. The effect of bleaching agent on the flavor of liquid whey and whey protein concentrate. J. Dairy Sci. 92:5917-5927.

Crudden, A., and A. L. Kelly. 2003. Studies of plasmin activity in whey. Int. Dairy J. 13:987-993.

Crudden, A., J. C. Oliveira, and A. L. Kelly. 2005. Kinetic studies of the thermal inactivation of plasmin in acid or sweet whey. Int Dairy J. 15:1245-1253.

de Wit, J. N., and A. C. M. van Hooijdonk. 1996. Structure, functions and applications of lactoperoxidase in natural antimicrobial systems. Neth. Milk Dairy J. 50:227-244.

Deeth, H. C. 2006. Lipoprotein lipase and lipolysis in milk. Int. Dairy J. $16: 555-562$

Drake, M. A. 2006. Flavor and flavor carry-through of whey proteins in beverages. Pages 292-300 in The Wonders of Whey . . . Catch the Power. Proc. 4th Intl. Whey Conf. American Dairy Products Institute, Elmhurst, IL.

Drake, M. A. 2007. Invited review: Sensory analysis of dairy foods. J. Dairy Sci. 90:4925-4937.

Drake, M. A., S. C. McIngvale, P. D. Gerard, K. R. Cadwallader, and C. V. Civille. 2001. Development of a descriptive language for Cheddar cheese. J. Food Sci. 66:1422-1427.

Drake, M. A., R. E. Miracle, and J. M. Wright. 2009. Sensory properties of dairy proteins. Pages 429-448 in Milk Proteins: From Expression to Food. A. Thompson, M. Boland, and H. Singh, ed. Elsevier, New York, NY.

Dwivedi, B. K., K. M. Shahani, and R. G. Arnold. 1973. The role of enzymes in food flavors. Part 1: Dairy products. CRC Crit. Rev. Food Technol. 3:457-478.

FAO/WHO (Food and Agriculture Organization of the United Nations/World Health Organization). 2005. Benefits and potential risks of the lactoperoxidase system of raw milk preservation. Accessed Dec. 31, 2012. ftp://ftp.fao.org/docrep/fao/009/a0729e/ a0729e00.pdf

Farkye, N., and P. F. Fox. 1992. Contribution of plasmin to Cheddar cheese ripening: Effect of added plasmin. J. Dairy Res. 59:209 216.

Fox, P. F., and A. L. Kelly. 2006a. Indigenous enzymes in milk: Overview and historical aspects-Part 1. Int. Dairy J. 16:500-516.

Fox, P. F., and A. L. Kelly. 2006b. Indigenous enzymes in milk: Overview and historical aspects-Part 2. Int. Dairy J. 16:517-532.

Fox, P. F. 2003. Significance of indigenous enzymes in milk and dairy products. Pages 255-277 in Handbook of Food Enzymology. J. R. Whitaker, A. G. J. Voragen, and D. W. S. Wong, ed. Marcel Dekker, New York, NY.

Gallardo-Escamilla, F. J., A. L. Kelly, and C. M. Delahunty. 2005. Sensory characteristics and related volatile flavor compound profiles of different types of whey. J. Dairy Sci. 88:2689-2699.

Griffiths, M. W. 1986. Use of milk enzymes as indices of heat treatment. J. Food Prot. 49:696-705.

Harrison, R. 2006. Milk xanthine oxidase: Properties and physiological roles. Int. Dairy J. 16:546-554. 
Havemose, M. A., M. R. Weisbjerg, W. L. P. Bredie, H. D. Poulsen, and J. H. Nielsen. 2006. Oxidative stability of milk influence by fatty acids, antioxidants and copper derived from feed. J. Dairy Sci. 89:1970-1980.

Hayes, K. D., and S. S. Nielsen. 2000. Plasmin levels in fresh milk whey and commercial whey protein products. J. Dairy Sci. 83:387-394.

Hayes, W., C. H. White, and M. A. Drake. 2002. Sensory aroma characteristics of milk spoilage by Pseudomonas species. J. Food Sci. $67: 448-454$.

Hickey, D. K., K. N. Kilcawley, T. P. Beresford, and M. G. Wilkinson. 2007. Lipolysis in Cheddar cheese made from raw, thermalized, and pasteurized milks. J. Dairy Sci. 90:47-56.

Huck, J. R., M. Sonnen, and K. J. Boor. 2008. Tracking heat-resistant, cold-thriving fluid milk spoilage bacteria from farm to packaged product. J. Dairy Sci. 91:1218-1228.

Hurley, M. J., L. B. Larsen, A. L. Kelly, and P. L. H. McSweeney. 2000. The milk acid proteinase, cathepsin D: A review. Int. Dairy J. 10:673-681.

Ismail, B., and S. S. Nielsen. 2010. Invited review: Plasmin protease in milk: Current knowledge and relevance to dairy industry. J. Dairy Sci. 93:4999-5009.

Jervis, S., R. Campbell, K. L. Wojciehowski, E. A. Foegeding, M. A. Drake, and D. M. Barbano. 2012. Effect of bleaching whey on sensory and functional properties of $80 \%$ whey protein concentrate. J. Dairy Sci. 95:2848-2862.

JervisS. M.DrakeM. A. 2013. The impact of iron on the bleaching efficacy of hydrogen peroxide in liquid whey systems. J. Food Sci. 78:R129-R137.

Kang, E. J., R. E. Campbell, E. Bastian, and M. A. Drake. 2010. Invited review: Annatto and bleaching in dairy foods. J. Dairy Sci. 93:3891-3901.

Karagül-Yüceer, Y., M. A. Drake, and K. R. Cadwallader. 2003. Aroma characterization of fresh and stored-nonfat dry milk. Pages 108-123 in ACS Symposium Series. Vol. 836. American Chemical Society, Washington, DC.

Kelley, E. E., N. K. H. Khoo, N. J. Hundley, U. Z. Malik, B. A Freeman, and M. M. Tarpey. 2010. Hydrogen peroxide is the major oxidant product of xanthine oxidase. Free Radic. Biol. Med. 48:493-498.

Kelly, A. L., and P. L. H. McSweeney. 2003. Indigenous proteinases in milk. Pages 495-521 in Advanced Dairy Chemistry: Volume 1: Proteins. P. F. Fox and P. L. H. McSweeney, ed. Kluwer Academic Publishers-Plenum Press, New York, NY.

Kelly, A. L., F. O'Flaherty, and P. F. Fox. 2006. Indigenous proteolytic enzymes in milk: A brief overview of the present state of knowledge. Int. Dairy J. 16:563-572.

Kitchen, B. J., G. C. Taylor, and I. C. White. 1970. Milk enzymesTheir distribution and activity. J. Dairy Res. 37:279-288.

Kosikowski, F. V. 1988. Enzyme behavior and utilization in dairy technology. J. Dairy Sci. 71:557-573.

Kussendrager, K. D., and A. C. M. van Hooijdonk. 2000. Lactoperoxidase: Physico-chemical properties, occurrence, mechanism of action, and applications. Br. J. Nutr. 84(Suppl. 1):S19-S25.

Liaw, I. W. H. Eshpari, P. S. Tong, and M. A. Drake. 2010. The impact of antioxidant addition on flavor of Cheddar and Mozzarella whey and Cheddar whey protein concentrate. J. Food Sci. 75:C559-C569

Liaw, I. W., R. E. Miracle, S. M. Jervis, M. A. D. Listiyani, and M. A. Drake. 2011. Comparison of the flavor chemistry and flavor stability of Mozzarella and Cheddar wheys. J. Food Sci. 76:C1188C1194.

Lindmark-Månsson, H., and B. Åkesson. 2000. Antioxidative factors in milk. Br. J. Nutr. 84(Suppl. 1):S103-S110.

Meer, R. R., J. Baker, F. W. Bodyfelt, and M. W. Griffiths. 1991. Psychrotrophic Bacillus spp. in fluid milk products: A review. J. Food Prot. 54:969-979.

Moatsou, G., C. Bakopanos, D. Katharios, G. Katsaros, I. Kandarakis, P. Taoukis, and I. Politis. 2008. Effect of high-pressure treatment at various temperatures on indigenous proteolytic enzymes and whey protein denaturation in bovine milk. J. Dairy Res. $75: 262-269$.
Morgan, M. E. 1976. The chemistry of some microbially induced flavor defects in milk and dairy foods. Biotechnol. Bioeng. 18:953-965.

Morr, C. V., and E. Y. W. Ha. 1991. Off-flavors of whey protein concentrates: A literature review. Int. Dairy J. 1:1-11.

Mortenson, M. A., Z. M. Vickers, and G. A. Reineccius. 2008. Flavor of whey protein concentrates and isolates. Int. Dairy J. 18:649-657.

Ranieri, M. L., and K. J. Boor. 2009. Short communication: Bacterial ecology of high-temperature, short-time pasteurized milk processed in the United States. J. Dairy Sci. 92:4833-4840.

Reginensi, S. M., M. J. González, J. A. Olivera, M. Sosa, P. Juliano, and J. Bermúdez. 2011. RAPD-based screening for spore-forming bacterial populations in Uruguayan commercial powdered milk. Int. J. Food Microbiol. 148:36-41.

Reiter, B., and B. G. Härnulv. 1982. The preservation of refrigerated and uncooled milk by its natural lactoperoxidase system. Dairy Ind. Int. 47:13-19.

Scheldeman, P., L. Herman, S. Foster, and M. Heyndrickx. 2006. Bacillus sporothermodurans and other highly heat-resistant spore formers in milk. J. Appl. Microbiol. 101:524-555

Seifu, E., E. M. Buys, and E. F. Donkin. 2005. Significance of the lactoperoxidase system in the dairy industry and its potential applications: A review. Trends Food Sci. Technol. 16:137-154

Silanikove, N., and F. Shapiro. 2007. Distribution of xanthine oxidase and xanthine dehydrogenase activity in bovine milk: Physiological and technological implications. Int. Dairy J. 17:1188-1194.

Singh, T. K., M. A. Drake, and K. R. Cadwallader. 2003. Flavor of Cheddar cheese: A chemical and sensory perspective. Compr. Rev. Food Sci. Food Saf. 2:166-189.

Singh, T. K., N. D. Young, M. Drake, and K. R. Cadwallader. 2005. Production and sensory characterization of a bitter peptide from $\beta$-casein. J. Agric. Food Chem. 53:1185-1189.

Smit, G., B. A. Smit, and W. J. M. Engels. 2005. Flavor formation by lactic acid bacteria and biochemical flavor profiling of cheese products. FEMS Microbiol. Rev. 29:591-610.

Thunell, R. K., J. W. Duersch, and C. A. Ernstrom. 1979. Thermal inactivation of residual milk clotting enzymes in whey. J. Dairy Sci. 62:373-377.

Timmons, J. S., W. P. Weiss, D. L. Palmquist, and W. J. Harper. 2001. Relationships among dietary roasted soybeans, milk components, and spontaneous oxidized flavor of milk. J. Dairy Sci. $84: 2440-2449$.

Tomaino, R. M., L. G. Turner, and D. K. Larick. 2004. The effect of Lactococcus lactis starter cultures on the oxidative stability of liquid whey. J. Dairy Sci. 87:300-307.

Urbach, G. 1995. Contribution of lactic acid bacteria to flavour compound formation in dairy products. Int. Dairy J. 5:877-903.

US FDA (US Food and Drug Administration). 2009. CFR - Code of Federal Regulations Title 21. 21CFR184.1366: Hydrogen peroxide. Accessed Oct. 29, 2012. http://www.accessdata.fda.gov/scripts/ cdrh/cfdocs/cfcfr/CFRSearch.cfm?fr=184.1366.

van Aardt, M., S. E. Duncan, J. E. Marcy, T. E. Long, S. F. O'Keefe, and S. R. Nielsen-Sims. 2005. Aroma analysis of light exposed milk stored with and without natural and synthetic antioxidants. J. Dairy Sci. 88:881-890.

Whitson, M. E., R. E. Miracle, E. Bastian, and M. A. Drake. 2011. Effect of liquid retentate storage on flavor of spray-dried whey protein concentrate and isolate. J. Dairy Sci. 94:3747-3760.

Whitson, M. E., R. E. Miracle, and M. A. Drake. 2010. Sensory characterization of chemical components responsible for cardboard flavor in whey protein. J. Sens. Stud. 25:616-636.

Wright, B. J., S. E. Zevchak, J. M. Wright, and M. A. Drake. 2009. The impact of agglomeration and storage on flavor and flavor stability of whey protein concentrate $80 \%$ and whey protein isolate. J. Food Sci. 74:S17-S29.

Wright, J. W., M. E. Carunchia Whetstine, R. E. Miracle, and M. Drake. 2006. Characterization of cabbage off-flavor in whey protein isolate. J. Food Sci. 71:C86-C90.

Yuan, D.-D., G.-C. Liu, D.-Y. Ren, D. Zhang, L. Zhao, C.-P. Kan, Y.-Z. Yang, W. Ma, Y. Li, and L.-B. Zhang. 2012. A survey on occurrence of thermophilic bacilli in commercial milk powders in China. Food Contr. 25:752-757. 